\title{
From Conventional to Blended Learning: Learning Technology Development for Plant Pest Science Course
}

\author{
My Syahrawati ${ }^{1, *}$ Yunisman $^{2}$ \\ ${ }^{1}$ Plant ProtectionDepartment, Facultyof Agriculture, Universitas Andalas Padang \\ ${ }^{2}$ Plant ProtectionDepartment, Faculty of Agriculture, Universitas Andalas Padang \\ *Corresponding author. Email: mysyahrawati@agr.unand.ac.id
}

\begin{abstract}
Plant Pest Science is a compulsory course of the Plant Protection Department, Faculty of Agriculture, Universitas Andalas. In the previous year, we teach students conventionally, standing in front of a class, and interact each other in the same place. This semester, we prepared the blended learning class by combining the i-learn site from university, pdf materials, learning videos, and virtual synchronous. The i-learn page was laid out more interested and informative so that there were emotional relationships between lecturer and students in there, even though only in writing form. The evaluation showed that the availability of learning videos and virtual synchronous meetings were enough to help improve students' understanding of this course.
\end{abstract}

Keywords: Distance learning, mix-method learning, traditional lecture, virtual lecture.

\section{INTRODUCTION}

The Plant Pest Science, abbreviated by PPS (course code: PPT 211), is a compulsory course in the Plant Protection Department, Faculty of Agriculture, Universitas Andalas, available for students in the third Semester. Students must pass the Basic Plant Protection Subject (in the second Semester) to take this course. The PPS is also a prerequisite for students before taking the Integrated Pest Management course (in Seventh Semester).

During one semester, the materials include pest introduction, pest grouping, pest success causes, internal and external factors that affect pest life, pest interactions with the environment, pest population dynamics, plant resistance mechanisms, population, and pest population growth models, and factors affecting pest population density $[1,2,3,4,5,6,7,8$, $9,10,11,12]$. To strengthen this lecturing, the teaching team has collected various materials commonly used on the international course. Based on those materials, the teaching team compiles powerpoints and practicumguidelines.

The learning method applied so far is conventional learning by direct face-to-face lectures or direct synchronous according to the university's schedule and classrooms. The material for each class meeting is prepared by lecturers in the form of powerpoints and delivered in lectures and discussions.

To deepen students' understanding of the PPS concept, lectures are also supported by scheduled practical activities. The practicum was carried out in the form of a simple experiment, such as the effect of external factors on insects' development. Practical guidelines are distributed to students as a term of reference.

The assessment carried out is for the presenting group, final papers, practicum, middle, and final examinations. In the odd Semester of 2019, the distribution of student scores ranges from 66-84 (grades A to B). None of the students scored a $\mathrm{C}$ or failed.

The limited interaction conditions currently occurring due to the Covid-19 pandemic have exposed lecturers and students to the choice of using other teaching techniques. In the last Semester of 2019, we have conducted online learning using the ilearn application. A simple discussion among students concluded that preparing a class with the 
virtual synchronous method and continued discussion forum was easier to understand than embedding the material just in i-learn. It is important to develop learning for PPS course through a blended learning program.

Blended learning as represents an opportunity to integrate the innovative and technological advances offered by online learning with the interaction and participation offered in the best of traditional learning [13]. Blended learning also described as a combined learning between face-to-face with learning by using technolog [14]. Furthermore, blended learning is a mixture of various learning strategies and delivery methods that will optimize the learning experience for its users [15]. It increases learning motivation and understanding of students related to the materials given. This research was done by prioritizing the development of material in i-learn, equipped with learning videos and then enriching with the virtual synchronous meeting.

\section{METHODOLOGY}

The learning technology development of plant pest science course has been started since July 2020 until now, with the main site located at i-learn university website: http://faperta.ilearn.unand.ac.id/.

\subsection{Revising Semester Learning Plans (SLP) and Practicum Guidelines}

The revision of SLP and practicum guidelines is necessary due to the course carried out face-to-face learning directly transformed into blended learning, in a combination of asynchronous and virtual synchronous learning. We conducted asynchronous learning by ma ximizing the use of the i-learn application, which provides pdf materials and learning videos. The classes are practically synchronous by working face-to-face learning using the zoom or google meet applications. The practicum, which was previously carried out in groups and the laboratory as a whole, changed to carry out independently in each location themselves.

\subsection{Improving Course Materials and Producing Learning Videos}

In the previous learning, course materials were made by each teacher in their respective class in the form of power points. This year, to meet the blended learning program's criteria, the course materials were equalized for all classes and varied with learning videos. Making instructional videos were done to make students easier to understand the materials and repeat as needed.

\subsection{Arrangement of Site Display at I-learn of University}

After the learning materials were made, the i-learn page needed to be arranged, make it more attractive and understandable.

\subsection{Subscribe to Virtual Synchronous Application}

To replace the direct synchronous meetings that students wish, we suscribed suitable alternatives, such as using the zoom or googlemeet applications. The lecturer can use one application account in all parallel classes.

\subsection{Learning Evaluation}

We carried out the learning evaluation twice; those were after the seventh and fourteenth meetings. The assessment was made via google form and filled out by students online.

\section{RESULTS AND DISCUSSION}

\subsection{Results}

\subsubsection{Revising SLP and Practicum Guidelines}

The PPS course is divided into 4 classes which are managed by eight lecturers. In order to have a similar perception, a teaching team meeting was held on 8 August 2020 which discussed changes to the SLP and practicum guidelines according to OBE. The SLP also has been adjusted to the conditions of distance learning (Figure 1).
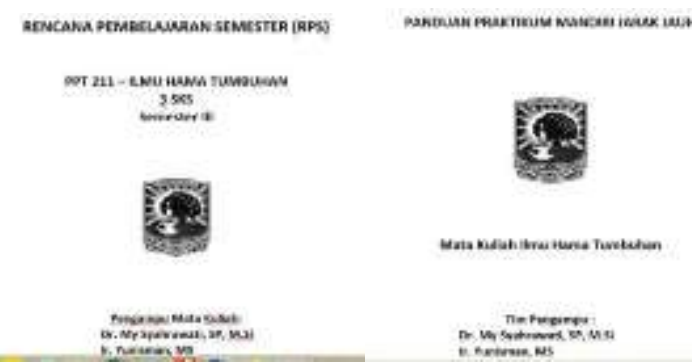

Figure 1 The Semester Learning Plan and practicum guidelines revised based on the OBE

\subsubsection{Improving Course Materials and Producing Learning Videos}

The weekly learning materials were revised and strengthened, and the design was improved. All classes can use these materials (Figure 2). Besides, four learning videos have been made to help students understand the course (Table 1, Figure 2).

\subsubsection{Arrangement of Course Site Display at I- learn}

Before this semester, the PPS course has never 
been presented in i-learn, so that the first thing to do is arrange the i-learn display to be more attractive, comfortable and understandable for students. The front page of i-learn was currently equipped with illustrations of lecturers, course descriptions, and SLP. Besides, the materials that students must obtain before mid-semester were displayed in i-learn. Students could access all any time without a time limit (Figure 4).
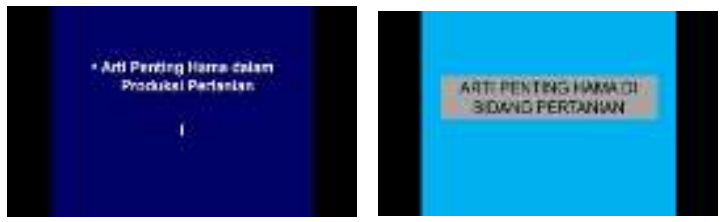

Before

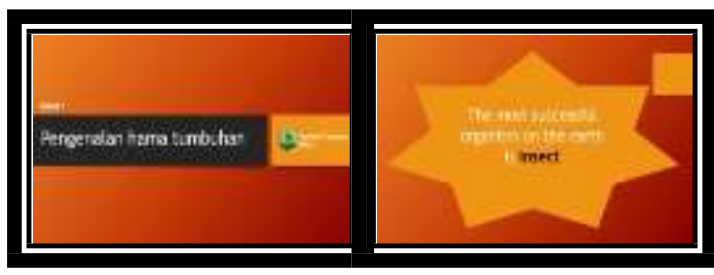

After

Figure 2 The design and display of the weekly material for the Plant Pest Science course, A. Last year, B. This year

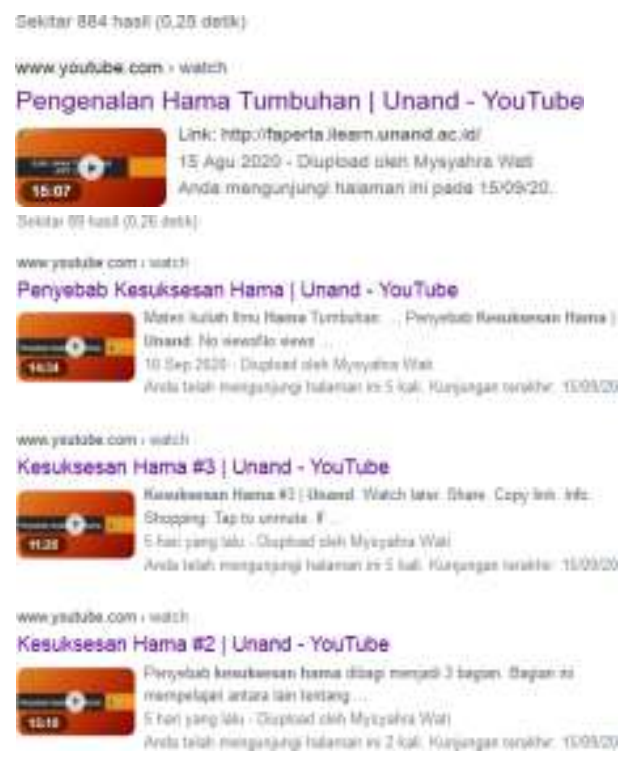

Figure 3 Display learning videos on YouTube with different materials but with the same design, so that students easily recognize it.

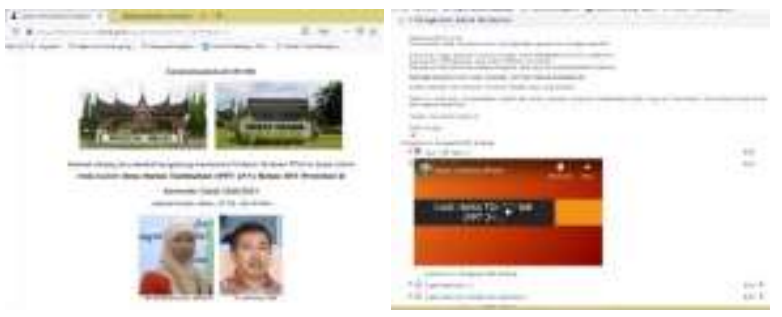

Figure 4 The screen display of i-learn in the Plant Pest Science course, left: opening greeting, right: course material.

Table 1 The links of learning videos for PPS course on YouTube

\begin{tabular}{|l|l|}
\hline $\begin{array}{l}\text { Materi } \\
\text { Pembelajar } \\
\text { an }\end{array}$ & Link untuk mengakses di youtube \\
\hline $\begin{array}{l}\text { Pengenalan } \\
\text { Hama } \\
\text { Tumbuhan }\end{array}$ & https://www.youtube.com/watch?v=jQ1ZB6nohco \\
\hline $\begin{array}{l}\text { Penyebab } \\
\text { kesuksesan } \\
\text { hama I }\end{array}$ & https://www.youtube.com/watch?v=DDcougsqfLA \\
\hline $\begin{array}{l}\text { Penyebab } \\
\text { kesuksesan } \\
\text { hama II }\end{array}$ & $\underline{\text { https://www.youtube.com/watch?v=PUbNkdEeW38 }}$ \\
\hline $\begin{array}{l}\text { Penyebab } \\
\text { kesuksesan } \\
\text { hama III }\end{array}$ & $\underline{\text { https://www.youtube.com/watch?v=YiXQQJADxew }}$ \\
\hline $\begin{array}{l}\text { Ketahanan } \\
\text { tanaman } \\
\text { terhadap } \\
\text { hama }\end{array}$ & $\underline{\text { https://youtu.be/tyQWYLnqmLI }}$ \\
\hline $\begin{array}{l}\text { Manajemen } \\
\text { hama }\end{array}$ & $\underline{\text { https://youtu.be/6NxX_0odVlg }}$ \\
\hline
\end{tabular}

\subsubsection{Subscribe to Virtual Synchronous Application}

Government policy to implement higher education with distance learning methods needs to be circumvented using applications that allow lectures to be conducted in virtual synchronous. Related to that, we conducted class and practicum using the zoom and googlemeet applications (Figure 5).
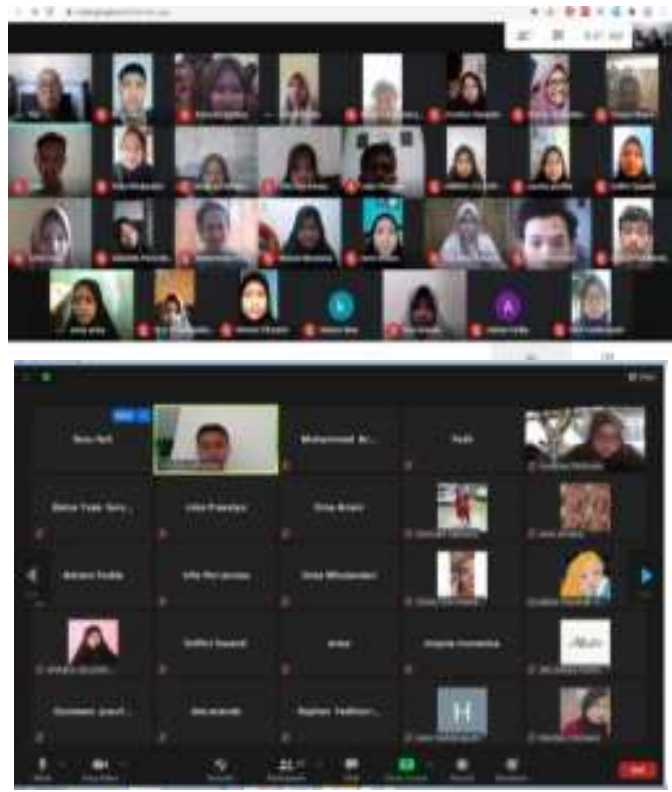


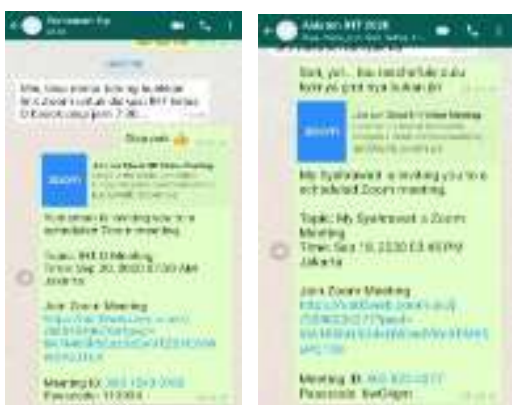

Figure 5 Class meeting and practicum through virtual synchronous; Above. The class meeting discussion

Middle. The practicum meeting with the assistant, Below. The zoom links that were distributed to students to participate in lecture and practicumdiscussions.

\subsubsection{Learning Evaluation}

Blended learning using an i-learn application from university and combining with pdf materials, learning videos, and virtual synchronous meetings has been held on seven class meetings. A simple evaluation has been done through a google form.

Our students generally understand the current situation of the Covid pandemic, so students hoped the learning videos will be reproduced more (42\%), but actually they still hope to get direct synchronous learning (27\%) (Figure 6A). Blended learning carried out before midsemester was considered to help the understanding of students (55.9\%) (Figure 6B). Of all the materials, the easiest to understand by students was the introduction of plant pests because accompanied by a learning video (6C). Finally, $97.1 \%$ stated that learning videos help improve their understanding (Figure 6D).

\subsection{Discussion}

Blended learning should make lecturers and students easier to carry out the educational process and work together to achieve beneficial goals. Blended learning also should provide opportunities for lecturers and students to learn independently, increases scheduling flexibility, and then face-to-face meetings could engage lecturers and students in interactive experiences.

We have made many changes in presenting this PPS course through this program, starting from revising the RPS and practicum guidelines, updating course materials, making learning videos, and arranging i-learn sheets to be more interesting and communicative. Next, we replaced direct synchronous with virtual synchronous so that it is still possible to do face-to-face learning even if it is virtually.

The learning technology development we arrange is classified as a web course model [16], where lecturers and students are completely separate. Teaching materials, discussions, consultations, assignments, exercises, exams, and other learning activities are entirely delivered through online. Refer to Carman [17], our blended learning development has fulfilled five primary keys: self-paced learning, performance supporting materials, live events, collaboration, and assessment.

The short assessment turned out that the learning video was an exciting point for students because it allowed them to learn the course material repeatedly whenever they needed it. Besides hoping that direct synchronous learning will increase, students also hope that the number of learning videos will also be increased. This is because the PPS course is classified as a basic course where students still really need guidance to understand better the various theories that have been raised.

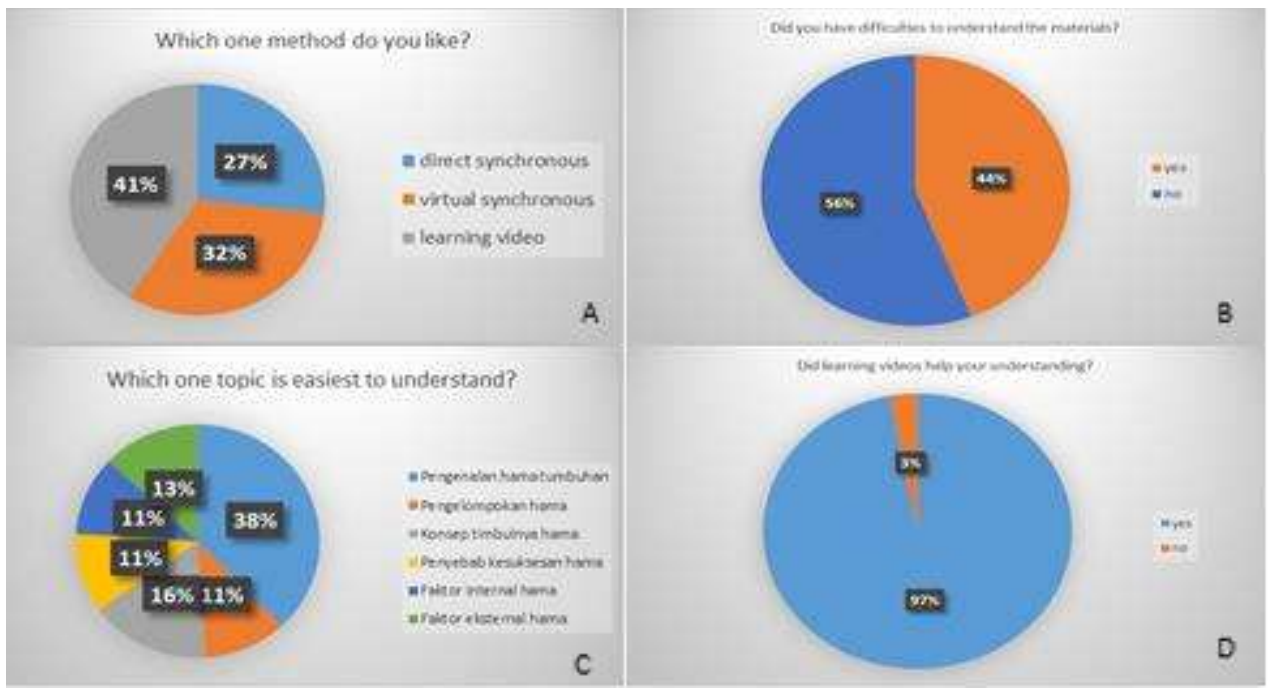

Figure 6 Learning evaluation for blended learning of Plant Pest Science Course in Plant Protection Department Universitas Andalas; A. Which method do you like?, B. Do you have difficulties to understand the materials?, C. Which one topic is easiest to understand?, D. Did larning videos help your understanding? 


\section{CONCLUSION}

Organizing Plant Pest Science Course using the blended learning method required much effort to make some changes, such as revising the Semester Learning Plan, revising course and practicum materials, preparing i-learn display correctly, and providing online lecture facilities using the zoom, the google meet, and also learning videos. Of all these efforts, providing learning videos was exciting and very helpful for students.

\section{AUTHORS' CONTRIBUTIONS}

MS participated in the design of the project, prepared the proposal of study learning, produced and shared the learning video, edited the supporting materials weekly, and prepared the manuscript. YY helped to prepare the i-learn page and questionnaire for learning evaluation, and helped to improve the discussion site of the manuscript. The two authors read and approved the final manuscript.

\section{ACKNOWLEDGMENTS}

We gratefully acknowledge to Educational Development and Quality Assurance Institutions Universitas Andalas that funded this study with the Program of Development and Implementation of Blended Learning, contract number: T.21/UN.16.18/PT.01.03/2020.

\section{REFERENCES}

[1] H.C.J. Godfray, 1994, Parasitoids behavioral and evolutionary ecology, Princeton University Press, Jew Jersey.

[2] P.W. Price, 1997, Insect ecology, $3^{\text {rd }}$ edition, John Wiley \& Son, Canada.

[3] R.F. Chapman, 1998, The Insect; Structure and function, $4^{\text {th }}$ edition, Cambridge University Press, United Kingdom.

[4] A.F.G. Dixon, 2000, Insect predator-prey dynamic, Cambridge University Press, United kingdom.

[5] C. Gillott, 2005, Entomology, $3^{\text {rd }}$ edition, Springer, Dodrecht.

[6] C.A. Triplehorn, N.F. Johnson, 2005, Borror and delongs introduction to study of insect, $7^{\text {th }}$ edition. Brooks/Cole, USA.

[7] E. Ranta, P. Lunberg, V. Kaitala, 2006, Ecology of population, Cambridge University Press, New York.

[8] T.D. Schowalter, 2006, Insect ecology; An ecosystems approach, Elsevier, USA.

[9] M.R. Speight, M.D Hunter, A.D. Watt, 2008, Concepts and applications: Insect ecology, $2^{\text {nd }}$ edition, Wiley-Blackwell, United Kingdom.

[10] E. Wajnberg, C. Bernstein, J. Alphen, 2008. Behavior ecology of insect parasitoids, Blackwell, United Kingdom.
[11] P.J. Gullan, P.S. Cranston, 2010, The Insect; An outline of entomology, $5^{\text {th }}$ edition, Blackwell, Australia.

[12] K.H. Thorne, 2003, Blended learning: How to integrate online and traditional learning, Kagan Page Limited, London.

[13] C.J. Bonk, C.R Graham, 2006. Handbook of blended learning: Global perspectives, local designs, Pfeiffer, San Francisco.

[14] A. Heinze, C. Procter, 2010. The Significance of the reflective practitioner in blended learning, International Journal of Mobile and Blended Learning 2(2):18-29.

[15] S. Bibi, H. Jati, 2015, Efektivitas model blended learning terhadap motivasi dan tingkat pemahaman mahasiswa mata kuliah algoritma dan pemograman, Jurnal Pendidikan Vokasi 5(1): $74-87$.

[16] M. Haughey, T. Anderson, 1998, Networking learning: The Pedagogy of the internet, Cheneliere/ McGraw-Hill, Montreal.

[17] J.M. Carman, 2005, Blended learning design: Five key ingredients, Knowledge.net. 